\title{
Analisis Statistik pada Dampak Negatif dari Sosial Media Terhadap Perilaku Manusia
}

\author{
Pradana Agung ${ }^{1}$, Fitri Marisa ${ }^{2}$ \\ ${ }^{1}$ kodokbeku45@gmail.com, ${ }^{2}$ fitrimarisa@widyagama.ac.id
}

Jurusan Informatika, Fakultas Teknik, Universitas Widyagama Malang

\begin{abstract}
This journal was created to explore the causes of the negative social media impacts that have occurred in the community. The aim is to examine the behavior of social media users among others. Social media is currently used in various ways such as shopping online, sharing news, advertising, and political news.The development of social media usage has grown enormously.however, the impact that will occur cannot be controlled if it is not addressed as quickly as possible. there are several social media usage behaviors that must be observed such as selfies, online shopping, offline meetings, self-control and shared culture. Through this journal, readers are expected to be able to see this phenomenon in the complete perspective of social media.
\end{abstract}

Intisari - Jurnal ini dibuat untuk menelusuri penyebab dampak negatif sosial media yang sudah terjadi di kalangan masyarakat. Tujuannya memeriksa perilaku pengguna sosial media antar sesama. Sosial media sekarang ini digunakan dalam berbagai hal seperti belanja online, berbagi berita, periklanan, dan berita politik. Perkembangan penggunaan sosial media tumbuh sangat. namun, dampak yang akan terjadi tidak dapat terkontrol bila tidak diatasi secepat mungkin. ada berberapa sosial media perilaku penggunaan yang harus di amati seperti selfie, belanja online, pertemuan offline, kontrol diri dan budaya bersama. melalui jurnal ini diharapkan pembaca dapat melihat fenomena ini dalam perspektif lengkap dari social media.

Kata Kunci-kontrol diri, sosial media, budaya bersama, belanja online

\section{PENDAHULUAN}

Perkembangan ilmu pengetahuan dan teknologi di era globalisasi dan modernisasi saat ini semakin canggih[1]. Di samping itu, tersebarnya informasi serta akses telekomunikasi dengan transportasi makin bertambah mudah dan cepat[1]. Internet adalah hasil dari kemajuan ilmu pengetahuan serta teknologi buatan manusia. Fungsi internet bermacam-macam, dan salah satunya adalah sebagai tempat komunitas jejaring sosial media[2]. Sosial media dapat berkomunikasi jarak jauh dengan menggunakan jaringan internet[2].

Di Indonesia mengakses sudah menjadi hal sehari-hari bagi remaja untuk aktivitas di kehidupannya. Penggunaan internet diantaranya sebagai sarana mencari data informasi, media hiburan berupa bermain game online, media komunikasi dengan menggunakan sosial media, bahkan untuk keperluan berbelanja dan berdagang banyak diantara mereka yang menggunakan online shop shopping secara online di internet[3]. Fenomena sosial media yang terjadi saat ini mereka rela membuang waktunya hanya untuk bermain game online dan internet[4]. Kecanduan sosial media, khususnya dengan menggunakan perangkat smartphone sudah dapat memberikan dampak negatif kepada manusia[4]. Sebelum adanya smartphone, orang dengan mudahnya saling menyapa dan melakukan kontak langsung. Sekarang ini banyak orang memiliki cara maupun alasan untuk menghindar komunikasi secara langsung dan lebih mementingkan komunikasi dengan media sosial di smartphone miliknya. Manusia sudah dianggap sebagai objek, tidak lagi sebagai manusia selayaknya mereka berteman [5].

Ohio State University meneliti, bahwa internet dapat membuat nilai belajar seorang pelajar menurun. Studi mengungkapkan bahwa, pelajar yang menghabiskan waktunya untuk mengakses internet akan lebih memilih mengakses internet dari pada belajar [6].Para pelajar menghabiskan waktunya berjam-jam hanya untuk mencari teman chatting yang akan mengakibatkan kehilangan waktunya untuk urusan akademik. Penelitian yang dilakukan dengan facebook dan dunia akademis terhadap pelajar sebanyak 219 pelajar Amerika Serikat.Hasil penelitian yaitu $68 \%$ subjek pengguna media sosial menggunakkan facebook setiap hari. Waktu yang dihabiskan oleh para pelajar terhadap penggunaan facebook beragam, mulai dari beberapa menit sampai lebih dari 3 jam lamanya. Hasil para peneliti melihat nilai akademis pelajar mengalami penurunan yang sangat drastis. Perilaku kecanduan karena menggunakkan internet dapat terjadi oleh banyak sebab diantaranya adalah kemampuan individu dalam mengontrol dirinya[7]. Kontrol diri adalah unsur penting untuk dapat terbebas dari perilaku kecanduan[8].

Istilah sosial media tersusun dari dua kata, yakni "Media" dan "Sosial". "Media" diartikan menjadi alat untuk 
berkomunikasi[9][10]. Sedangkan kata "sosial" juga diartikan menjadi setiap individu yang melakukan tindakan sosial dapat memberikan kontribusi kepada masyarakat umum. Pernyataan ini menegaskan ternyata pada penggunaan sosial media dan semua alat-alat elektronik merupakan tindakan "sosial" atau dalam artian lain bahwa penggunaan sosial media serta media komunikasi merupakan hasil dari proses social[11].

Sekarang ini sosial media sudah menjadi faktor penting bagi manusia sebagai alat komunikasi[10]. Tetapi dengan adanya media sosial ini, dapat membuat seseorang terlalu terbuka terhadap dirinya dihadapan orang lain ataupun dengan orang yang belum dikenalnya. Selain itu, media sosial ternyata tidak hanya memberikan dampak postif tetapi juga memberikan dampak negatif. Salah satunya ialah perubahan karakter dan sifat seseorang dari penggunaan teknologi terutama media komunikasi[4]. Ditambah dengan adanya smartphone yang menyediakan kemudahan bersosial media dan provider yang menyediakan layanan sosial media secara murah.

Hasil riset yang dilakukan oleh Kompas menunjukkan masyarakat memiliki ketertarikan untuk menggunakan online shop dengan angka sebesar 19,9\% pada tahun 2012. Pada umumnya masyarakat berbelanja online tidak berdasarkan pada kebutuhan utama, melainkan untuk kesenangan dan gaya hidup yang menyebabkan secara individu boros akan kebutuhan atau bisa dikenal dengan istilah perilaku konsumtif atau perilaku konsumerisme[12].

Pola budaya sedikit demi sedikit berubah dan serta mulai merubah pola pikir kita karena adanya dedia sosial. Seseorang terhadap media sosial dapat menjadikannya ketergantungan akan pengunaanya, Penyalahgunan sosial media sering digunakan untuk pencemaran nama baik, Membagikan situs porno, dan cybercrime atau penipuan dalam internet. Karena itu, didalam karya tulis ini akan diukur seberapa banyak penggunaan sosial media sekarang ini[13].

\section{METODE PENELITIAN}

\section{A. Analisa Data}

Langkap awal pengumpulan data yaitu dengan memakai teknik sampling incidental.Setelah data yang dibutuhkan dalam penelitian sudah terkumpul, langkah kedua yang harus dikerjakan adalah analisis terhadap data. Analisis data merupakan suatu proses untuk menentukan urutan data, mengorganisasikannya membentuk suatu pola, ketagorisasi dan satuan uraian dasar. Analisis data dikerjakan untuk dapat mengkaji dan mengolah data yang sudah dikumpulkan sehingga dapat menghasilkan kesimpulan yang sesuai dengan rencana dalam penelitian.Teknik analisis data yang digunakan dalam penelitian ini adalah analisis data regresi.

\section{B. Populasi dan Sampel}

Populasi dalam penelitian ini adalah pelajar serta masyarakat umum yang mempunyai karakteristik sebagai berikut :

1. Mempunyai akun media sosial,

2. Mengakses internet selama 4jam / hari,

3. Transaksi Belanja Online.

Tabel 1. Sampel Incidental

\begin{tabular}{|c|l|c|c|c|}
\hline No & Kriteria & Jumlah & Ya & Tidak \\
\hline 1. & $\begin{array}{l}\text { Mengakses Internet } \\
\text { selama 4jam/ hari }\end{array}$ & 20 & 12 & 8 \\
\hline 2. & $\begin{array}{l}\text { Memiliki akun media } \\
\text { sosial media }\end{array}$ & 16 & 10 & 6 \\
\hline
\end{tabular}

Teknik incidental adalah mengambil penjawab atau responden sebagai sampel berdasarkan kebetulan, yaitu penggunaan sampel apabila orang yang kebetulan ditemui oleh peneliti layak sebagai sumber data[14]. Cara pemilihan sampel terhadap penelitian ini ialah dengan memakai teknik sampling incidental. Dari Table 1ditemukan 12 orang yang cocok.

\section{Metode Pengumpulan Data}

Dalam hal ini metode yang akan diterapkan ialah metode analisis statistik. Penelitian ini menggunakan analisis statistik dan diolah oleh IBM dengan program terbaru komputasi SPSS(Statistical Package for Social Science).

Skala yang dipakai dalam penelitian ini terdiri daridua, yaituSkalaSkala Kontrol Diri dan Kecanduan Media Sosial. Kedua skala tersebut menerapkanperubahan dari skala likert, dengan menetapkan empat alternatif respon, yaitu SRG (Sering), KDG (Kadang), JRG (Jarang) danTDP (Tidak Pernah).

Tabel 2. Kuesioner skala likert

\begin{tabular}{|c|l|c|c|c|c|}
\hline No. & Variable & SRG & KDG & JRG & TDP \\
\hline 1. & $\begin{array}{l}\text { Mengakses Media } \\
\text { Sosial }\end{array}$ & 3 & 2 & 5 & 2 \\
\hline 2. & $\begin{array}{l}\text { Transaksi Belanja } \\
\text { Online }\end{array}$ & 2 & 1 & 2 & 7 \\
\hline
\end{tabular}

\section{HASIL DAN PEMBAHASAN}

Perhitungan analisis regresi berganda sebagai berikut, $\mathrm{Y}=\mathrm{A}+\mathrm{B}_{1} \mathrm{X}_{1}+\mathrm{B}_{2} \mathrm{X}_{2+} \mathrm{e}$

Dimana:

$\mathrm{Y}=$ kontrol diri,

$\mathrm{A}=$ konstata,

$B_{1}, B_{2}=$ Koefisien garis regresi/slope,

$\mathrm{X}_{1}=$ media sosial,

$\mathrm{X}_{2}=$ belanja online

$\mathrm{e}=$ error $/$ residual $/$ variable penggangu . 


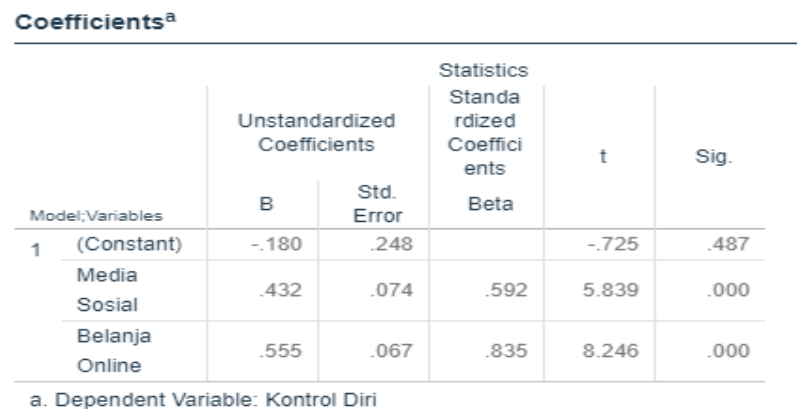

Gambar 1. Regresi liniear berganda

ANOVA $^{\text {a }}$

\begin{tabular}{|c|c|c|c|c|c|c|}
\hline \multirow{2}{*}{\multicolumn{2}{|c|}{ Model;Source }} & \multicolumn{5}{|c|}{ Statistics } \\
\hline & & $\begin{array}{l}\text { Sum of } \\
\text { Squares }\end{array}$ & df & $\begin{array}{l}\text { Mean } \\
\text { Square }\end{array}$ & $\mathrm{F}$ & Sig. \\
\hline \multirow[t]{3}{*}{1} & Regression & 6.290 & 2 & 3.145 & 45.184 & $.000^{\mathrm{b}}$ \\
\hline & Residual & .626 & 9 & .070 & & \\
\hline & Total & 6.917 & 11 & & & \\
\hline
\end{tabular}

Gambar 2. Linieritas Regresi

Hasil uji hipotesis penelitian yang memakai teknik analisis regresi berganda pada gambar 1 melalui program dari IBM yaitu SPSS (Statistical Package for Social Science), diperoleh hasil korelasi $=-0,180$ pada gambar 2 diperoleh nilai Signifikansi, Sig. $=0,000(\mathrm{p}<0,005)$. Sehingga hasil dari koefisien korelasi tersebut mengindikasikan adanya hubungan antara variabel kontrol diri dengan kecanduan media sosial.

Tingkat signifikan sebesar Sig. $<0,005$ menunjukkan adanya hubungan yang signifikan antara kontrol diri dengan kecenderungan kecanduan media sosial. Angka negatif pada koefisien korelasi memperlihatkan ternyata rendahnya kemampuan kontrol diri, maka kecanduan media sosial akan semakin tinggi, Begitu sebaliknya, tingginya kemampuan kontrol diri yang dimiliki, maka kecenderungan kecanduan media sosial akan semakin rendah.

Mengakses Media Sosial

\begin{tabular}{|c|c|c|c|c|c|}
\hline \multirow{2}{*}{\multicolumn{2}{|c|}{$\begin{array}{l}\text { Mengakses Media } \\
\text { Sosial }\end{array}$}} & \multicolumn{4}{|c|}{ Statistics } \\
\hline & & Frequency & Percent & Valid Percent & Cumulative Percent \\
\hline \multirow[t]{5}{*}{ Valid } & 1.00 & 2 & 16.7 & 16.7 & 16.7 \\
\hline & 2.00 & 5 & 41.7 & 41.7 & 58.3 \\
\hline & 3.00 & 2 & 16.7 & 16.7 & 75.0 \\
\hline & 4.00 & 3 & 25.0 & 25.0 & 100.0 \\
\hline & Total & 12 & 100.0 & 100.0 & \\
\hline
\end{tabular}

Gambar 4. Skala likert pengguna media sosial
Hasil data hipotetik kecanduan media sosial didapatkan sebanyak 2 orang $(16,7 \%)$ berada pada kategori sangat rendah, 5 orang $(41,7 \%)$ berada pada kategori rendah, 2 orang $(16,7 \%)$ berada pada kategori tinggi dan 3 orang $(25,0 \%)$ berada pada kategori sangat tinggi. Hal ini menunjukkan bahwa kecenderungan kecanduan media terhadap masyarakat berada pada kategori rendah. Masyarakat yang mempunyai tingkat kecanduan media sosial rendah bisa dikatakan meskipun mereka mengakses media sosial setiap hari namun pikiran, tingkah laku dan perasaan mereka tidak didominasi oleh keinginan untuk menggunakan media sosial, serta media sosial tidak menghalangi hubungan sosial dan kegiatan dengan lingkungan sekitarnya.

Kemampuan masyarakat dalam membatasi perilaku dan menahan godaan merupakan salah satu upata yang dapat menghindari untuk memiliki kecenderungan terhadap kecanduan media sosial. Kontrol diri menyebabkan perorangan mampu menahan diri dari hawa nafsu sehingga mereka berperilaku dengan benar berdasarkan hati dan pikiran. Kontrol diri menyadarkan individu terhadap konsekuensi terhadap bahaya atas tindakan yang akan dilakukan sehingga bisa mengontrol emosinya.

Transaksi Belanja Online

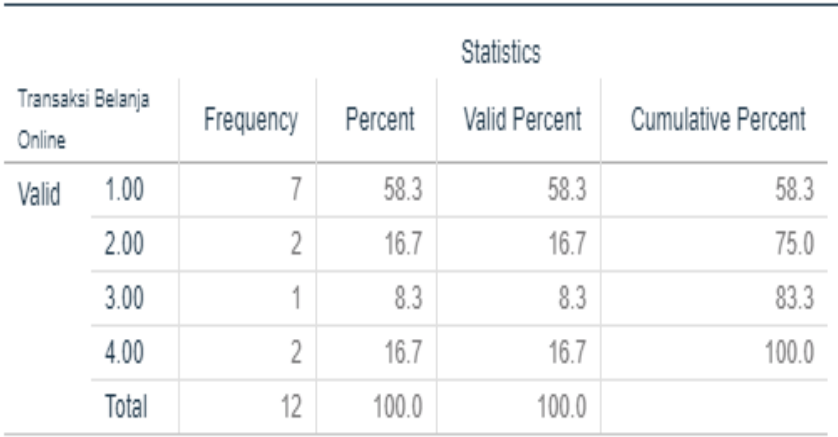

Gambar 5. Skala likert belanja online

Berdasarkan hasil penelitian terdapat 1 orang $(8,3 \%)$ berada pada kategori tinggi, dan $2(16,7 \%)$ orang berada pada kategori sangat tinggi dalam kecenderungan kecanduan online shopping . Munculnya kecanduan media sosial diawali dengan proses mengamati dan rasa ingin mencoba, bila menunjukkan penguatan positif maka penguat tersebut akan memberi masing masing individu untuk mengulangi tingka lakunya secara terus menerus. Kecanduan (addiction) diartikan sebagai suatu tingkah laku ketagihan yang dikembangkan individu pada suatu aktivitas tertentu. Kecanduan juga bisa terbilang sebagai keterlibatan terus - menerus pada sebuah kegiatan walaupun akan berdampak konsekuensi negatif.

Kategorisasi hipotetik data kontrol diri pada subjek penelitian memperlihatkan bahwa sebanyak 3 orang $(25,00 \%)$ memiliki tingkat kontrol diri tinggi dan 5 orang $(41,70 \%)$ 
memiliki kontrol diri sangat tinggi. Hasil ini memperlihatkan bahwa rata - rata subjek mempunyai kontrol diri yang tinggi, artinya sanggup mengendalikan tingkah laku dan menahan godaan yang tampak dari dalam diri sehingga dapat mengambil suatu langkah untuk mencapai hasil yang diinginkan serta mencegah akibat yang tidak diinginkan. Menyatakan bahwa perorangan yang memiliki kontrol diri tinggi berkorelasi dengan tersedianya penyesuaian yang lebih baik, lebih bisa menetapkan emosi secaraoptimal, kurangnya patologi dan dapat menjalin hubunganbersama orang lain.

Model Summary

\begin{tabular}{|c|c|c|c|c|}
\hline \multirow[b]{2}{*}{ Model } & \multicolumn{4}{|c|}{ Statistics } \\
\hline & $\mathrm{R}$ & $\begin{array}{c}\mathrm{R} \\
\text { Square }\end{array}$ & $\begin{array}{l}\text { Adjusted R } \\
\text { Square }\end{array}$ & $\begin{array}{l}\text { Std. Error of the } \\
\text { Estimate }\end{array}$ \\
\hline 1 & $.954^{\mathrm{a}}$ & .909 & .889 & .264 \\
\hline
\end{tabular}

Angka koefisien determinasi yang diperoleh pada penelitian ini sebesar 0,909. Angka tersebut mempunyai arti bahwa dalam penelitian ini kontrol diri mempunyai kontribusi efektif sebesar 90,9\% terhadap kecanduan media sosial. Sisanya 9,1\% ditentukan oleh faktor lain yang tidak diungkap pada penelitian ini, sekiranya faktor kepribadian seseorang, faktor lingkungan sosial dan faktor motivasi.

\section{KESIMPULAN DAN SARAN}

Tingkah laku manusia yang makin bertambah setiap hari tidak terpisahkan dari (kenyataan) dunia maya patut menjadi perhatian yang menguatirkan, Berdasarkan pendapat - pendapat di atas, bisa disimpulkan ternyata individu dapat memunculkan kecanduan media sosial berkaitan dengan kemampuan untuk melakukan penguasaan terhadap tingkah lakunya atau kontrol diri. Kemampuan kontrol diri yang dimiliki perorangan sanggup membuat mereka terhindar pada kecanduan pada media sosial maupun belanja online yang berlebihan.

Saran yang bisa diberikan terhadap hasil penelitian, pembahasan, dan simpulan ialah untuk subjek penelitian yang mempunyai tingkat kecanduan media sosial rendah dan kontrol diri tinggi diharapkan untuk bisa menajaga dan mempertahankan kemampuan untuk mengontrol diri yang sudah dimiliki.Bagi subjek yang mempunyai tingkat kontrol diri tinggi dan kecanduan media sosial tinggi diharapkan untuk mau mengembangkan kontrol diri yang dimiliki. Masyarakat diharapkan mengembangkan kontrol diri atas faktor yang dimiliki di dirinya masing - masing, supaya dengan adanya kemampuan untuk mengontrol diri yang akan dikembangkan dari dalam diri mampu mengurangi dan mencegah kecanduan media sosial.

\section{DAFTAR PUSTAKA}

[1] A. Ahmad, "Perkembangan Teknologi Komunikasi Dan Informasi," 2012.

[2] N. I. Setyani, S. Hastjarjo, and N. N. Amal, "Penggunaan Media Sosial Sebagai Sarana Komunikasi bagi Komunitas," 2013.

[3] A. Loekamto, "Implementasi Technology Acceptance Model (Tam) Dalam Online Shopping," pp. 1-5, 2012.

[4] A. Y. Aljawiy and A. Muklason, "Jejaring Sosial Dan Dampak Bagi Penggunanya," Sist. Inf., 2012.

[5] D. Goleman, Social intelligence. .

[6] W. Buente and A. Robbin, "Trends in internet information behavior," J. Am. Soc. Inf. Sci. Technol., vol. 59, no. 11, 2008.

[7] R. Aditya, "Pengaruh Media Sosial Instagram Terhadap Minat Fotografi Pada Komunitas Fotografi Pekanbaru," Jom FISIP Oktober H.R. Soebrantas Km, vol. 2, no. 12, 2015.

[8] H. S. Widiana, S. Retnowati, and H. Rahma, "Kontrol Diri Dan Kecenderungan Kecanduan Internet," Indones. Psychol. J., vol. 1, no. 1, pp. 6-16, 2004.

[9] D. Laughey, Media Theory. 2007.

[10] D. McQuail, TEORI KOMUNIKASI MASSA. .

[11] C. Fuchs, Social Media a Critical Introduction. .

[12] J. Hasugian, "Pemanfaatan Internet: Studi kasus tentang Pola, Manfaat dan Tujuan Penggunaan Internet oleh Mahasiswa pada Perpustakaan USU," Pustaha J. Stud. Perpust. dan Inf., vol. 1, no. 1, pp. 7-18, 2005.

[13] M. Borba, Membangun Kecerdasan Moral. 2008.

[14] Sugiyono, Statistika Untuk Penelitian. 2011. 